\title{
Challenges in the diagnosis and management of Pseudohypoaldosteronism Type 1
}

\author{
Uma Visser $^{1 *}$, Paul Jenkins ${ }^{1,2}$, Tony Lafferty ${ }^{1,2}$ \\ From 8th APPES Biennial Scientific Meeting \\ Darwin, Australia. 29 October - 1 November 2014
}

Autosomal recessive Pseudohypoaldosteronism Type I (PHA-I, MIM\#264350), is a rare disease with a severe clinical phenotype $[1,2]$ and generally no improvement with age [3]. It results from mutations in the amiloridesensitive epithelial sodium channel causing mineralocorticoid-resistant $(\mathrm{ENaC})$, systemic salt wasting, and is lethal without ongoing supra-physiological sodium supplementation and management of hyperkalaemia $[4,5]$.

Other manifestations of systemic PHA-I include decreased sodium-dependant clearance of alveolar fluid causing recurrent chest congestion, cough and wheeze, but no airway infection by bacterial pathogens typifying cystic fibrosis[6,7]; and skin rashes from inflammation of sodium-blocked sweat glands [8] with recurrent Staphylococcal skin infections described [9].

Our patient, now nearly four years old, presented as a day 6 neonate with vomiting, apnoea and floppiness. She was shocked and dehydrated with hyponatraemia, marked hyperkalaemia with runs of ventricular tachycardia.

PHA-1 was diagnosed with high cortisol, renin and aldosterone, normal 17-hydroxyprogesterone, inappropriately high spot urine sodium with low potassium, and normal renal ultrasound. Diagnosis was genetically confirmed with the finding of two inherited, distinct, disease causing mutations in the SCNNIA gene. Increased sweat sodium confirmed systemic salt-wasting. Initial management included a high-sodium, low-potassium formula (Kindergen) supplemented with $22 \mathrm{mmol} / \mathrm{Kg} /$ day of enteral sodium, the use of daily potassium binding resin (Resonium), and trial of Fludrocortisone.

Requirement for daily large doses of sodium $16 \mathrm{mmol} /$ $\mathrm{Kg} /$ day, provided as a mix of sodium citrate and sodium chloride, and daily Resonium continues. Significant oral aversion remains an issue with good growth achieved on calorie-concentrated Kindergen. Gastrostomy feeding

Department of Paediatrics, The Canberra Hospital, Canberra, ACT, Australia Full list of author information is available at the end of the article was changed to percutaneous jejunal continual feeding due to persistent gastric emptying problems. Central venous access established early has posed ongoing challenges, with intermittent Staphylococcal infections. Our patient has also been hypertensive requiring medical management from 6 months age. She has a recurrent moist cough with past Haemophilus infection.

Minimising inpatient management is vital for establishing 'normality' and optimising development. The need for frequent electrolyte monitoring and adjustment of sodium intake is managed creatively between home and hospital in close liaison with her paediatric endocrinologist and community-based supports. Clear emergency management plans involving early symptom recognition and rapid hospital-access are instituted to manage salt-wasting episodes.

We shall discuss the challenges and pitfalls of managing this rare, life-threatening disease with sparse longterm prognostic information, in the Australian health care context.

Written informed consent was obtained from the parent of the patient for publication of this abstract and any accompanying images. A copy of the written consent is available for review by the Editor of this journal.

\section{Authors' details}

${ }^{1}$ Department of Paediatrics, The Canberra Hospital, Canberra, ACT, Australia. ${ }^{2}$ Australian National University, Canberra, ACT, Australia.

Published: 28 April 2015

\section{References}

1. Riepe FG: Clinical and molecular features of type 1 pseudohypoaldosteronism. Horm Res 2009, 72:1-9.

2. Zennaro MC, Lombes M: Mineralocorticoid resistance. Trends Endocrinol Metab 2004, 15:264-270.

3. Adachi M, Asakura Y, Muroya K, Tajima T, Fujieda K, Kuribayashi E, Uchida S: Increased $\mathrm{Na}$ reabsorption via the $\mathrm{Na}-\mathrm{Cl}$ cotransporter in autosomal recessive pseudohypoaldosteronism. Clin Exp Nephrol 2010, 14:228-232. 
4. Furgeson SB, Linas S: Mechanisms of type I and type II pseudohypoaldosteronism. J Am Soc Nephrol 2010, 21:1842-5.

5. Güran T, Deirmenci S, Bulut YK, Say A, Riepe FG, Giiran Ö: Critical points in the management of pseudohypoaldosteronism type I. J Clin Res Pediatr Endocrinol 2011, 3:98-100.

6. Kerem E, Bistritzer T, Hanukoglu A, et al: Pulmonary epithelial sodiumchannel dysfunction and excess airway liquid in pseudohypoaldosteronism. N Engl J Med 1999, 341:156-162.

7. Eaton DC, Helms MN, Koval M, et al: The contribution of epithelial sodium channels to alveolar function in health and disease. Annu Rev Physiol 2009, 71:403-23.

8. Urbatsch A, Palier AS: Pustular miliaria rubra: a specific cutaneous finding of type I pseudohypoaldosteronism. Pediatr Dermatol 2002, 19:317-9.

9. Saravanapandian N, Paul S, Matthai J: Pseudohypoaldosteronism Type 1: A Rare Cause of Severe Dyselectrolytemia and Cardiovascular Collapse in Neonates. J Clin Neonatol 2012, 1:224-6.

doi:10.1186/1687-9856-2015-S1-P126

Cite this article as: Visser et al.: Challenges in the diagnosis and

management of Pseudohypoaldosteronism Type 1. International Journal of Pediatric Endocrinology 2015 2015(Suppl 1):P126.

\section{Submit your next manuscript to BioMed Central} and take full advantage of:

- Convenient online submission

- Thorough peer review

- No space constraints or color figure charges

- Immediate publication on acceptance

- Inclusion in PubMed, CAS, Scopus and Google Scholar

- Research which is freely available for redistribution

Submit your manuscript at www.biomedcentral.com/submit 